\title{
THE IMPLEMENTATION OF THE PRINCIPLE OF INTEGRITY IN THE LEGISLATION RELATING WITH THE PROTECTION OF ULAYAT RIGHT ON ADAT LAW COMMUNITIES
}

\author{
Dian Arianto \\ Notary/Official certifier of title deeds, Batam City \\ Doctor candidate of Law Science at Universitas Padjajaran Bandung \\ E-mail: dian_syaiful@yahoo.com
}

\begin{abstract}
This study aims to identify and analyze the implementation of the principle of integrity in the legislation relating with the protection of ulayat rights on adat Law communities. This study used normative juridical approach. The results showed that the agrarian law as a basic reference settings related to the Natural Resources in relation to the Ulayat Rights with other regulations, particularly in Law Number 41 Year 1999, Law Number 6 Year 2014, Presidential Decree Number 71 Year 2012, and Regulation of the Ministry of Home Affairs Number 52 Year 2014 and Regulation of the Minister ATR/KBPN Number 10 Year 2016 shows the lack of synchronization substance and structure as the elaboration of the principles of integrity as mandated by the TAP MPR Number XI/MPR/2001
\end{abstract}

Keywords: the principle of integrity, ulayat rights, adat Law communities, legal protection

\section{Abstrak}

Penelitian ini bertujuan untuk mengetahui dan menganalisa pelaksanaan asas keterpaduan dalam perauran perundang-undangan yang berkaitan dengan hal perlindungan hak ulayat MHA. Penelitian ini menggunakan pendekatan yuridis normatif. Hasil penelitian menunjukkan bahwa antara UUPA sebagai acuan dasar penyusunan pengaturan yang berhubungan dengan Sumber Daya Alam (SDA) dalam kaitannya dengan Hak Ulayat dengan peraturan lainnya, khususnya dalam UU No. 41 Tahun 1999, UU No. 6 Tahun 2014, Perpres No. 71 tahun 2012, dan Permendagri No. 52 Tahun 2014 serta Permen ATR/KBPN No. 10 Tahun 2016 menunnjukkan tidak adanya sinkronisasi substansi dan struktur sebagai penjabaran asas keterpaduan sebagaiamana yang diamanatkan dalam TAP MPR No. XI/MPR/2001.

Kata kunci: asas keterpaduan, hak ulayat, masyarakat hukum adat, perlindungan hukum

\section{Introduction}

Sociologically, adat law communities are a form of social life that is laid out by adat law, ${ }^{1}$ in which there are elements in the form of: first, a group of residents who have a common ancestor; second, stay somewhere; third, have a common purpose in life to maintain and pre-serve norms value; fourth, there are adat Laws are adhered to and binding; fifth, led by Adat Chief; sixth, availability of administration

\footnotetext{
Sabardi, "Konstruksi Masyarakat Hukum Adat dalam Pa-sal 18B UUD RI", Jurnal Hukum dan Pembangunan, Tahun ke43 No. 2, April-June 2013, Jakarta: Faculty of Law Universitas Indonesia, page 179.
}

where power can be coordinated; seventh, there is a dispute resolution institutions. ${ }^{2}$

For adat law communities, Land and Natural Resources contained in it has a very important position, because it is the only thing permanent wealth, as well as a place to stay and other functions. ${ }^{3}$ Philosophically, control and ownership of land and Natural Resources loaded with the value of the background for the birth of legal norms that regulate the ownership of

2 Jawahir Thontowi, "Perlindungan dan Pengakuan Masyarakat Hukum Adat dan Tantangannya dalam Sistem Hukum Indonesia", Jurnal Hukum IUS QUIA IUSTUM, Vol. 2 No. 1, January 2013, Yogyakarta: Faculty of Law Universitas Islam Indonesia.

3 Rosalina, “Eksistensi Hak Ulayat di Indonesia”, Jurnal Sasi, Vol. 16 No. 3, July-September 2010, Ambon: Faculty of Law Universitas Pattimura, page 44. 
land tenure. ${ }^{4}$ The legal relationship between the adat Law communities and specific land/ region (object right) is called the Ulayat Rights, which contains the authority in the form of: first, Organize and administer the use of the land (for housing, farming and others), supplies (making settlements/new paddy field and etc), and ground maintenance; second, organize and determine legal relationship between people and the ground (giving certain rights on a particular subject); and third, organize and establish legal relations between people and legal acts pertaining to land (sale, inheritance, etc). ${ }^{5}$ Ulayat Rights is an identity for adat law communities, and protected its existence by 1945 Constitution. ${ }^{6}$

With regard to the rights of adat law communities, as has been described above that adat law has served as the basis of national agrarian law formation. The implementation of the rights of adat Law communities against land and natural resources are recognized, although it should be limited to a number of requirements. In practice, the government's recognition against the rights of adat Law communities are very rare or almost never happened. The rights deprivation of indigenous that mostly done ostensibly to serve the development purposes run by the investors both inside and outside the country. ${ }^{7}$

Legal protection is closely associated with the policies issued by the authorities, the power branches are run by people who assumed office (officials), so that the elements of nature (it can make a mistake, either intentionally or unintentionally) that is inherent in man by itself

\footnotetext{
4 Julius Sembiring, "Tanah Dalam Perspektif Filsafat IImu Hukum", Jurnal Mimbar Hukum, Vol. 23 No. 2, June 2011 edition, Yogyakarta: Faculty of Law Universitas Gadjah Mada, page 237.

5 Maria SW. Sumardjono, 2007: Kebijakan Pertanahan (Antara Regulasi dan Implementasi) Cetakan ke VII, Jakarta: Penerbit Buku Kompas, page 56.

6 Kurnia Warman dan Hengky Andora, "Pola Hubungan Hukum dalam Pemanfaatan Tanah di Sumatera Barat", Jurnal Mimbar Hukum, Vol. 26, No. 23, October 2014 edition, Yogyakarta: Faculty of Law Universitas Gadjah Mada, page 366.

7 Linda Yanti Sulistiawati dan Muhammad Adib Zaid, "Tanah dan Hukum Adat di Indonesia Timur", Jurnal Landreform, Vol 2, December 2014, Jakarta Selatan: Konsorsium Pembaharuan Agraria (KPA), page 29.
}

will cling on to power mentioned, in case of declares there are the potential emergence of actions contrary to the law, and violate the rights of citizens. Violation of adat Law communities's right itself usually occurs in material basis destruction to the way of original community that live, especially going through the eviction of the community, and then claiming the ownership of their land, modern country with strong economic partners can quickly take the lands of the indigenous communities. ${ }^{8}$

After the reform of 1998, carried out Agrarian Reform guided by the People's Consultative Assembly Decree Number IX/MPR/2001 concerning Agrarian Reform and Natural Resources Management (MPR Decree Number IX/ MPR/ 2001), considering that during the New Order era land policies tend toward capitalism that led to the liberalization and privatization. ${ }^{9}$ One of the principles against Agrarian Reform context on TAP MPR is the principle of integration to reconstruction efforts Indonesia's land law system, which means that need synchronization attempts substance, structure and culture as an element in legal system. ${ }^{10}$ The principle of integrity in charge of MPR Decree Number IX/MPR/ 2001 consists of; first, the same thoughts associated with other interrelated fields as consideration; second, the same substance or spirit to other areas are interlinked; third, the similarity of interests into orientation. ${ }^{11}$

This paper will disscuss about: how is the implementation of principle of integrity in legislation relating with the protecttion of Ulayat Rights on adat Law communities?

8 Nasarudin Tianotak, "Perlindungan Hukum Terhadap Hak Asasi Masyarakat Dalam Pengelolaan Sumber Daya Hutan di Provinsi Maluku", Jurnal Sasi, Vol.16 No. 4, OctoberDecember 2010, Ambon: Faculty of Law Universitas Pattimura, page 32 .

9 Nurhasan Ismail, "Arah Politik Hukum Pertanahan dan Perlindungan Kepemilikan Tanah Masyarakat”, Jurnal Rechtsvinding: Media Pembinaan Hukum Nasional, Vol. 1 No.1, April 2012, Jakarta: Pusat Analisis dan Evaluasi Hukum Nasional Kementerian Hukum dan HAM RI, Page 39.

10 Lawrence M Friedman, 1975, The Legal System A Social Science Perspective, New York: Russel Sage Foundation, page 15-19

11 Nurhasan Ismail, dkk, "Penjabaran Asas Pembaharuan Agraria Berdasarkan TAP MPR No. IX/MPR/2001 dalam Peraturan Perundang-Undangan di Bidang Pertanahan", Jurnal Mimbar Hukum, Vol. 22 No. 2, June 2010, Yogyakarta: Faculty of Law Universitas Gadjah Mada. page 261. 


\section{Discussion}

In many laws and regulations that applied in Indonesia, adat Law which have sanctioned, now began to get a proper place as a legal product. In many cases, such adat Law could contribute until some extent to ensure legal certainty and justice for people. The current law is even used as basis for a decision by the judges, so it can be seen that adat Law is efficient, effective and applicable when faced with today's modern society. Even in accordance with the authority of judges to hear and decide a case, obliged to prosecute values, norms and laws that live in community development ${ }^{12}$

The debate about existence of adat Law communities is deserving of legal protection in context of a country that was built in the early days of independence has gained a very large portion in the trial Committee Preparatory Work for Indonesian Independence (BPUPKI), ${ }^{13}$ which later crystallized in the explanation II Article 18 1945 Constitution (before amendment). As a form of implementation these norms, recognition, respect, and protection of indigenoue poeples rights manifest in Ulayat Rights recognition as stipulated in Article 3 of Law Noumber 5 Year 1960 concerning Provisions of Agrarian Law, which confirms that the State respects and recognizes the existence of Ulayat Rights on adat Law communities. The recognition of Ulayat Rights in the form of declaratory, that designation is affirmation, given adat right is an innate right of adat Law communities, ${ }^{14}$ as well as asserted in the Constitutional Court decision Number 3/PUU-VIII/2010 concerning judicial review

${ }^{12}$ Abuyazid Bustomi, "Keberadaan Hukum Tanah Adat Dalam Mewujudkan Tertib Hukum Agraria", Jurnal Solusi, Vol. 3 No. III, September 2013, Semarang: Universitas Semarang (USM), page 176.

13 Stated by Muh. Yamin on BPUPKI dated 11 July Year 1945, then by Supomo, which states that "there is a special area that has the original order, is Dorfgemeinschaffen, such as Java villages, villages in Minangkabau, village and clan in Palembang, Huta and Kuria in Tappanuli, village Aceh, on 15 July Year 1945 (Minutes of Business Session Investigation Agency Indonesian Independence (BPUPKI), "Indonesian Independence Preparatory Committee (PPKI) May 28 1945-22 August 1945", the State Secretary of the Republic of Indonesia, 1995, page 18 and 272.

14 Maria SW Sumardjono, 2015, Dinamika Pengaturan Pengadaan Tanah di Indonesia: Dari Keputusan Presiden Sampai Undang-Undang, First Edition, Yogyakarta: Gadjah Mada University Press, page 57. of Law Number 27 Year 2007 concerning Coastal Areas and Small Islands, the Constitutional Court ruling Number 35/PUU-X/2012 concerning judicial review of Law Number 41 Year 1999.

The third paragraph in General Explanation of Chapter II Agrarian Law about the goals of Agrarian Law, is as follows:

Due to everything that law of joints and provisions essentially need to be arranged in the form of Act, which will form basis for other regulation formulation. Even though that law is formally no different from other laws, ie a regulation made by the Government with House of Representatives approval, but given its nature as ground rules for agrarian law is new, then loaded inside just principles and problems staple in outline only and is called Basic Law Agraria. The implementation will be regulated in various laws, administrative regulations and other laws.

The explanations above show that charge content of Agrarian Law: first, binding provisions of the law, which is a hierarchical system of law equal, as well as the inferior related to $\mathrm{Na}$ tural Resources; and second, the charge contained in Agrarian Law is still abstract, so that required legislation other more elaborate principles contained in the Agrarian Law. The principal purpose of Agrarian Law was as follows: first, Laid the groundwork for the National agrarian law formulation, which would constitute a means to bring prosperity, happiness, and justice for the state and people, especially farmer, in the framework of a just and prosperous society; second, Laid the foundations to hold unity and simplicity in land law; and third, Laid the basics to provide legal certainty regarding the rights to the land for people entirely.

Recognition of Ulayat Rights in Article 3 of the Agrarian Law is a recognition of conditional, ie, according to its existence there is a continual basis, when it does not exist, can not be recalled, as well as by implementation that is in accordance with national interests and state based on national unity and not conflict with laws and other higher regulations. The provisions of Article 3 of Agrarian Law is not followed by the definition and criteria for deciding existence of 
Ulayat Rights, so it can not be im-plemented at level of empirical.

After the passing of the 1998 reforms, the reconstruction effort adat Law communities recognizing rights vigorously voiced by academics and activists, it later led to the birth lot of regulations relating to the rights of adat Law communities, which some of the rules which were canceled by Constitutional Court, including following: first, Article $18 \mathrm{I}$ and Article paragraph (2) and Article 28 I paragraph (3), 1945 Constitution Second Amendment (2000); second, the People's Consultative Assembly Decree Number IX/ MPR/2001 on Agrarian Reform and Natural Resources Management (TAP MPR Number IX/ MPR/2001); third, Article 5, paragraph (3), Article 6 paragraph (1) and Article 6 paragraph (2) of Law No. 39 Year 1999 concerning Human Rights; fourth, Article 1 number 6, Article 5 paragraph (1) and Article 5 paragraph (2) of Law Number 41 Year 1999 concerning Forestry (Decision Session of the Constitutional Court of the Republic of Indonesia Number 35/PUU-XI/2012, replace the provisions of Article 1, number 6 with the sound of "adat forest is a forest in the area of adat Law communities" and cancel Article 5 (1) provided that the state forests excluding adat forest, that mean adat forest is its own entity in addition to state forest and private forest).

Fifth, Article 34 paragraph (2) of Law Number 22 Year 2001 concerning Oil and Gas; Sixth, Article 1 paragraph (38), Article 18, Article 61 paragraph (1 and 2) of Law Number 27 Year 2007 concerning the Management of Coastal Areas and Small Islands (Constitutional Court Decision Number 3/PUU-VIII/2010 annul Article 1 paragraph 18, Article 16, Article 17, Article 19, Article 20, Article 21, Article 22, Art-icle 23 paragraph (4) and (5), Article 50, Article 60 paragraph (1), Article 71 and Article 75, this law because it is considered incompatible with 1945 Constitution, which restricts the access of indigeneous peoples to their sea Ulayat Rights; seventh, Article 1 paragraph (32) and (33), Article 21 paragraph (1), Article 22 paragraph (1) and (2), Article 60 paragraph (1) letter (c) and (d) of Law Number 1 Year 2014 concerning the
Amendment of Law Number 27 Year 2007 concerning the Management of Coastal Areas and Small Islands; eighth, Law Number 4 Year 2009 concerning mining; ninth, Article 7, paragraph (3) of Law Number 26 Year 2007 concerning Spatial Planning.

Tenth, Article 6 paragraph (2) of Law Number 31 Year 2004 concerning Fisheries; eleventh, Article 3, paragraph (2) and (3) of Law Number 11 Year 1974 concerning Water Resources Management. (Constitutional Court Decision Number 85/PUU-XII/2013, cancel the validity of the entire contents of Law Number 7 Year 2004 concerning Water Resources Manage-ment, thus the Law Number 11 Year 1974 automatically back into a legal umbrella for water resources management. Protection of adat Law communities rights in Law Number 11 Year 1974 contained in the provisions of Article 3 paragraph (3) of this law, the implementation of right to control the country as defined in paragraph (2), respecting the rights owned by local adat Law communities, to extent not contrary with national interest); twelfth, Article 4 (letter c), Article 6 paragraph (1) and (2), Article 8 paragraph (2) and (4), Article 67 paragraph (1) letter a, Article 96, Article 97 of Law Number 6 Year 2014 concerning Village.

In addition there is an executor of regulation among the other things, PMNA/K BPN Number 5 Year 1999 which was later repealed and replaced by the Permen ATR/K BPN Number 10 Year 2015 concerning Agrarian and Spatial Planning Minister/Head of National Land Agency Number 10 Year 2016 concerning Procedures for Determining the Communal Land Rights of Adat Law communities and Communities Being in a Specific Region (Permen ATR/KBPN Number 10 Year 2016) replaces PMNA/KBPN Number 5 Year 1999. There is also the Presidential Decree No. 71 Year 2012 concerning the Implementation of Land Procurement for Development in the Public Interest, and Permendagri Number 52 Year 2014 concerning Guidelines for the Protection of Adat Law communities.

Substantially, Permen ATR/KBPN Number 10 Year 2016 which specifically regulates the recognition, recognition, and respect for Ulayat 
Rights of adat Law communities would lead to confusion in the use of term, by equating the notion of Ulayat Rights and communal rights which actually has different characteristics (Article 1 (1) Permen ATR/K BPN Number 10 Year 2016), Ulayat Rights concerning the dimensions of public law and civil law, while communal rights dimension relates only to civil law. ${ }^{15}$ Communal rights itself included in the category of land rights, it does show that Ulayat Rights is considered as a right granted by the state equal to land rights contained in Article 16 Agrarian Law. On the othern hand in Article 22 paragraph (2) of Presidential Decree Number 71 Year 2012 stated that the existence of Ulayat Rights recognized after their determination through local regulations. Determination of the existence of Ulayat Rights (or in Permen ATR/K BPN Number 10 Year 2016 referred to as communal rights) and Presidential Decree No. 71 Year 2012 is constitutive, suggesting that the State is all rights giver, whereas Ulayat Rights is an innate right of adat Law communities.

The lifting PMNA/KBPN Number 5 Year 1999 also causes loss of foundation in determining the existence of Ulayat Rights, considering only PMNA/KBPN which specifically includes criteria recognizing adat land rights as set out in Article 2 PMNA, after the period of 39 (thirtynine) powerful New-Order the recognition of Ulayat Rights is not followed by a determinant criterion of existence, so it can not be run on the empirical level. Although during applicable PMNA/KBPN Number 5 Year 1999 also does not necessarily resolve agrarian conflict in relation to Ulayat Rights, one reason is that PMNA only applies within the jurisdiction of BPN, not in the forest area is jurisdiction of Ministry of Forestry, whereas in reality that adat Law communities is living in forest areas. As for the sectoral laws that have been mentioned above as set out in Article 67 paragraph (1) of Law Number 41 Year 1999, Article 97 of Law Number 6 Year 2014, and Article 5 paragraph (2) Permendagri Number 52 Year 2014 as well as Permen ATR/ KBPN Number 10 Year 2016 just set adat Law

\footnotetext{
${ }^{15}$ Maria SW. Sumardjono, "Ihwal Hak Komunal Atas Ta-
} nah", Kompas, Monday, 6 July 2015. communities existence as a legal subject, does not set criteria for the ongoing Ulayat Rights.

In the terms of structural, then Article 2 paragraph (4) Agrarian Law can be considered as legal basis for affairs division in land between central government and local governments. ${ }^{16}$ Relation to the Ulayat Rights, authority establishment to grant recognition, respect, and protection of Ulayat Rights in Article 22 paragraph (2) of Presidential Decree Number 71 Year 2012, enough with the Local Government provisions, as well as in Article 6 of Regulation Number 52 Year 2014 concerning existence recognition of adat Law communities. While in PMNA Number 10 Year 2016, the authority to grant recognition of Ulayat Rights done in stages, first established by the Regional Head, then submitted to the Regional Office of $\mathrm{Na}$ tional Land Agency issued a certificate of communal rights. It certainly limit local governments movement to determine their own regulations on Ulayat Rights of adat Law communities, according to social conditions of people, especially adat Law communities. Yet in practice during this time, there have been some areas that also involves adat Law communities in lawmaking on Ulayat Rights recognition, such as adat Law communities of Kajang in Bulukumba, adat Law communities of Baduy in Lebak, adat Law communities of Malinau in North Borneo, ${ }^{17}$ thus setting Ulayat Rights as The Living Law does not ignore standpoint of adat Law communities itself in defining their own Ulayat Rights.

The explanation above shows that content consistency and recognition of adat Law communities Ulayat Rights structure in support rules which elaborated integration principle contained in MPR Decree Number IX/MPR/2001 is questionable. Constitutional Court Decision Number 3/PUU-VIII/2010 regarding judicial re-

\footnotetext{
16 Supriyanto, "Kewenangan Bidang Pertanahan dalam Pelaksanaan Otonomi Daerah", Jurnal Dinamika Hukum, Vol. 9, No. 2, May 2009, Purwokerto: Faculty of Law Universitas Jenderal Soedirman, page 162

17 Willem van der Muur and Adrian Bedneer, Process of Legal Recognition For The Ammatoa Kajang Community", Jurnal Mimbar Hukum, Volume 28, Number 1, February 2016 Edition, Yogyakarta: Faculty of Law Universitas Gadjah Mada, page 155
} 
view of Law Number 27 Year 2007 on Coastal Areas and Small Islands, the Constitutional Court ruling Number 35/PUU-X/2012 on judicial review of Law Number 41 Year 1999, has put Ulayat Rights on actual position, so with the provisions of Article 3 of Agrarian Law which asserts that the State's obligation is more a recognition which is done through confirmation (declaratory) and not constitutive determination, because Ulayat Rights existence of adat Law communities does not depend only on determination, but the fact that Ulayat Rights is still ongoing. ${ }^{18}$ Thus, it was fitting indeed what has been specified in Article 5 (2) PMNA/K BPN Number 5 Year 1999, that is quite Ulayat Rights stated in the Land Registry map. We should also note the state agency authorized to make inaugural Ulayat Rights of adat Law communities, given the existence of two institutions that have same authority will bear a different legal product that could potentially hamper efforts to provide legal certainty and the implications for the legal safeguards for Ulayat Rights of adat Law communities.

Conflict of Dayak Simpakg, associated overlapping allotment of land for the company's permit on indigenous lands, the conflict of adat Law communities of Benuaq in East Kalimantan with HPTI in Production Forest, the conflict of adat Law communities of Peminggir, Lampung on Protected Forest Management, as well as the Conflict of adat Law communities of Bunaken, North Sulawesi on management of Bunaken Marine Park and many others indicate that adat Law communities problems can not be resolved completely and thoroughly.

\section{Conclusion}

Based on the above explanation it can be concluded that between Agrarian Law as a basic reference settings related to Natural Resources preparation in relation to Ulayat Rights with other regulations, particularly in PMNA Number 10 Year 2016, Presidential Decree Number 71 Year 2012, and Regulation Number 52 Year 2015 showed no synchronization of content and struc- ture as mandated in MPR Decree Number $\mathrm{XI} /$ MPR/2001.

\section{Suggestion}

It is necessary to make change against the settings on recognition, respect and protection of adat Law communities Ulayat Rights in accordance with the concept of Ulayat Rights, the changes are carried out selectively, if indeed there are provisions those are still relevant its logically to use in recognition, respect, and protection of Ulayat Rights of adat Law communities, one of the PMNA provisions Number 5 Year 1999. It should also be noted harmonization and synchronization between rules that contain the same substance.

\section{References}

Bustomi, Abuyazid. "Keberadaan Hukum Tanah Adat dalam Mewujudkan Tertib Hukum Agraria”. Jurnal Solusi. Vol. 3 Number III. September 2013. Semarang: Universitas Semarang (USM);

Friedman, Lawrence M. 1975 . The Legal System: A Social Science Perspective. New York: Russel Sage Foundation;

Ismail, Nurhasan. "Arsah Politik Hukum Pertanahan dan Perlindungan Kepemilikan Tanah Masyarakat". Jurnal Rechtsvinding: Media Pembinaan Hukum Nasional. Vol. 1 No. 1. April 2012 Edition. Jakarta: Pusat Analisis dan Evaluasi Hukum Nasional Kementerian Hukum dan HAM RI;

Ismail, Nurhasan. dkk. "Penjabaran Asas Pembaharuan Agraria Berdasarkan TAP MPR No. IX/MPR/2001 Dalam Peraturan Perundang-Undangan di Bidang Pertanahan". Jurnal Mimbar Hukum. Vol. 22 No. 2. June 2010. Yogyakarta: Law Faculty Universitas Gadjah Mada;

Risalah Sidang Badan Penyelidik Usaha Kemerdekaan Indonesia (BPUPKI). "Panitia Persiapan Kemerdekaan Indonesia (PPKI) 28 Mei 1945-22 Agustus 1945". Jakarta: Sekretariat Negara Republik Indonesia. 1995;

Rosalina. "Eksistensi Hak Ulayat di Indonesia". Jurnal Sasi. Vol. 16 No. 3. July-September 2010 Edition. Ambon: Law Faculty Universitas Pattimura;

\footnotetext{
${ }^{18}$ Maria SW Sumardjono, 2015, op.cit. page 57
} 
Sabardi. "Konstruksi Masyarakat Hukum Adat dalam Pasal 18B UUD RI". Jurnal Hukum dan Pembangunan. $43^{\text {th }}$ No. 2. April-June 2013. Jakarta: Law Faculty Universitas Indonesia;

Sembiring, Julius. " Tanah Dalam Perspektif Filsafat Ilmu Hukum". Jurnal Mimbar Hukum. Vol. 23 No. 2. June 2011. Yogyakarta: Law Faculty Universitas Gadjah Mada;

Sulistiawati, Linda Yanti dan Muhammad Adib Zaid. "Tanah dan Hukum Adat di Indonesia Timur”. Jurnal Landreform. Vol 2. December 2014. Jakarta Selatan: Konsorsium Pembaharuan Agraria (KPA);

Sumardjono, Maria SW. 2007. Kebijakan Pertanahan (Antara Regulasi dan Implementasi) 7th Edition. Jakarta: Penerbit Buku Kompas;

2015. Dinamika Pengaturan Pengadaan Tanah di Indonesia: Dari Keputusan Presiden Sampai Undang-Undang. $1^{\text {st }}$ Edition. Yogyakarta: Gadjah Mada University Press;

-.-.-.. "Ihwal Hak Komunal Atas Tanah". Kompas. Monday. 6 July 2015.

Supriyanto. "Kewenangan Bidang Pertanahan dalam Pelaksanaan Otonomi Daerah".
Jurnal Dinamika Hukum. Vol. 9. No. 2. May 2009 Edition. Purwokerto: Law Faculty Universitas Jenderal Soedirman;

Thontowi, Jawahir. "Perlindungan dan Pengakuan Masyarakat Hukum Adat dan Tantangannya dalam Sistem Hukum Indonesia". Jurnal Hukum IUS QUIA IUSTUM. Vol. 2 No. 1. January 2013. Yogyakarta: Law Faculty Universitas Islam Indonesia;

Tianotak, Nasarudin. “Perlindungan Hukum Terhadap Hak Asasi Masyarakat Dalam Pengelolaan Sumber Daya Hutan di Provinsi Maluku". Jurnal Sasi. Vol. 16 No. 4. October-December 2010. Ambon: Law Faculty Universitas Pattimura;

van der Muur, Willem and Adrian Bedneer. "Process of Legal Recognition For The Ammatoa Kajang Community". Jurnal Mimbar Hukum. Vol. 28 No. 1. February 2016 Edition. Yogyakarta: Law Faculty Universitas Gadjah Mada;

Warman, Kurnia dan Hengky Andora. "Pola Hubungan Hukum dalam Pemanfaatan Tanah di Sumatera Barat". Jurnal Mimbar Hukum. Vol. 26 No. 23. October 2014 Edition. Yogyakarta: Law Faculty Universitas Gadjah Mada. 